\title{
INTERACTIVE DEBATE CLUB TECHNIQUES DURING DISTANCE LEARNING WITH PHYSICAL EDUCATION STUDENTS
}

Summary. At the age of COVID 19 the methodoligist of all the countries faced a new image of cognitive culture, which implies a greater level of independent activity from the student. The teacher got the task of forming this high level. The article emphasizes that for the formation of basic skills of public speaking in a foreign language and the development of communicative competence of students, it is advisable to use such pedagogical technology as debate. Debate is a modern pedagogical technology, which is a special form of discussion, which is conducted according to certain rules. It is a purposeful and orderly, structured exchange of ideas, judgments, opinions. It is emphasized that debates in the educational process occur in the following forms: as a form of lesson; as an element of the lesson: actualization of knowledge, organization of independent work of students, generalization, systematization, consolidation of educational material, providing "feedback"; as a form of attestation and testing of students. It is determined that the target functions and capabilities of the "Debate" technology are wide. The socializing significance is expressed in the fact that debate is a pedagogical tool, a mechanism for involving participants in the norms and values of civil society, which allows students to adapt to modern society, which involves the ability to compete, debate, defend their interests based on existing knowledge and skills. knowledge. The educational value is manifested in the fact that the debate allows participants to develop independence of assessments, moral and ideological position and behavioral attitudes. Debate participants have a higher communication culture, the ability to find a compromise. Developmental significance is expressed in the fact that the debate allows participants to develop will, memory, thinking, including the ability to compare, compare, analyze, find analogies, independently extract and analyze a variety of information on issues relevant to man and society. Didactic value is expressed in the fact that the debate is the basis for the formation of students' general skills and practical skills, as well as the most important qualities needed by modern man. In general, despite the difficulties that arise in the first attempts to adapt the debate to the conditions of the student audience, with the correct organization of all stages of work, this technology can significantly increase the motivation and quality of knowledge acquired by students.

Keywords: debate, method, cooperation, dialogue, communication.

Шевченко М.Ю.

\section{ІНТЕРАКТИВНІ МЕТОДИ КЛУБУ ДЕБАТІВ ПІД ЧАС ДИСТАНЦІЙНОГО НАВЧАННЯ ЗІ СТУДЕНТАМИ ФАКУЛЬТЕТУ ФІЗИЧНОГО НАВЧАННЯ}

Анотація. У статті наголошено, що для формування основних навичок публічного виступу на іноземній мові і розвитку комунікативної компетенції учнів, доцільно використовувати таку педагогічну технологію як дебати. Дебати являють собою сучасну педагогічну технологію, що е особливою формою дискусії, яка проводиться за певними правилами. Це цілеспрямований і впорядкований, структурований обмін ідеями, судженнями, думками. Підкреслено, що дебати в навчальному процесі зустрічаються в наступних формах: як форма уроку; як елемент уроку: актуалізація знань, організація самостійної роботи учнів, узагальнення, систематизація, закріплення навчального матеріалу, забезпечення «зворотного зв'язку»; як форма атестації та тестування учнів. Визначено, що цільові функції і можливості технології «Дебати» широкі. Соціалізуюче значення виражається в тому, що дебати е педагогічним засобом, механізмом залучення учасників до норм і цінностей громадянського суспільства, що дозволяе учням адаптуватися до умов сучасного суспільства, який передбачає вміння конкурувати, вести полеміку, відстоювати свої інтереси на основі наявних знань і вміння застосовувати ці знання. Виховне значення проявляеться в тому, що дебати дозволяють учасникам виробляти самостійність оцінок, морально-світоглядну позицію і поведінкові установки. Учасники дебатів мають більш високу комунікативну культуру, здатністю знайти компроміс. Розвиваюче значення виражається в тому, що дебати дозволяють учасникам розвивати волю, пам'ять, мислення, включаючи вміння зіставляти, порівнювати, аналізувати, знаходити аналогії, самостійно добувати і аналізувати різнопланову інформацію з актуальних для людини і суспільства проблем. Дидактичне значення виражається в тому, що дебати є основою для формування у студентів загальнонавчальних умінь і практичних навичок, а також найважливіших якостей, необхідних сучасній людині. В цілому, не дивлячись на труднощі, які виникають при перших спробах адаптації дебатів до умов студентської аудиторії, при правильній організащії всіх етапів роботи, ця технологія дає можливість значно підвищити мотиващію і якість придбаних учнями знань.

Ключові слова: дебати, метод, співпраця, діалог, комунікація.

The problem of research. One of the main tasks of teaching a foreign language is a communicative task. For achieving successful communication, i.e., the ability to exchange information with each other, students need to learn how to interact with each other.
The "Debate" method is one of the most effective techniques to achieve successful speech interaction between communicants. This technique allows you to integrate and involve a large number of students in the process of speech interaction at the same time, and also with the help of it, you can consid- 
er and discuss current modern problems that students will be interested in themselves.

By integrating various kinds of debates in foreign language lessons, the teacher thereby contributes to the awakening of children's interest in the study of the subject.

Analysis of research and publications. The development of socio-cultural competence in foreign language lessons are devoted to research by Domnina T.V., Zavyalova N.A., Lavrentyeva A.P., Trubina G.V. and others. Implementation in he educational process of intensive learning methods is reflected in the works Golovanova I.I., Svetenko T.V., Halina S.M., Quinn S., Morozovoy T.V. and others.

The aim of the article is to analyze the methods and process of the use of debates during the distance learning of English.

Main material. First of all, the "debate" technique forms all four basic language communication skills in students - listening, reading, speaking, and writing. In accordance with the normative documents, these skills must be developed by a foreign language teacher.

In addition to the development of language skills directly, the "debate" technique forms the skills of public speaking. It has been proven that one of the main reasons for the fear of schoolchildren speaking a foreign language in public is their lack of communication skills and experience in public speaking their native language. Debate teaches such speech tactics which will allow students to communicate more effectively in the future, speak at international seminars and conferences, participate in discussions with foreigners, defend their own opinions aloud, and speak a foreign language publicly.

In the senior classes, "debates" can be used to generalize, systematize and consolidate educational material, and also act as control speaking. However, it must be borne in mind that not every topic can be a subject of discussion, it must be correctly formulated, as a rule, by a teacher.

The preparation and conduct of the debate involve the organization of work in groups (teams). The teacher can create teams themselves, assigning roles, or students create groups on their own, and the roles are distributed by mutual agreement. A group can include neighbors in desks or rows.

Before conducting a direct debate, a serious preliminary preparation of students is needed. At this stage, techniques are often used to stimulate the creative and critical thinking of school children, such as "brainstorming" or "mind maps" (memory cards).

The "brainstorming" technique is used at the stage of direct generation and selection of ideas and assumes the observance of several principles. First of all, goals, objectives, and constraints are formulated. Participants in the discussion are provided with maximum freedom: giving the word to everyone (encouraging the shy, "sticking to" the most active and authoritative), as well as complete freedom of opinion, encouraging "crazy" ideas and analogies. The discussion is carried out hierarchically: first - the maximum "breadth", then the assessment of the prospects of options and the selection of the best, then again "breadth". While using the brainstorming method, the role of a facilitator and capturing ideas are important.

Students of the "Civil Engagement Club", Debate Club "Per aspera ad astra" and "English Access Mi- croscholarship Program" use brainstorming games in every lesson. For example, on the first session of the "Civil Engagement Club", we played the game "What superpower would you like to have?" with the help of the online tool "Mentimeter". Learners had to pick any superpower and explain their choice. Also, during the session participants brainstormed some ideas of possible ways to stop bullying, what we can do and what people we should influence.

At the class of the English language with students of the physical education faculty the possible topics of debate can be:

Who is stronger in powerlifting men or women?

How to stop ageism in sport?

What is the age to start professional sport?

Can a good player can be a couch or trainer?

The main idea of the "mind mapping" method is to reject the usual "linear" records and fix the information in a graphical form in the form of a branching crown of a tree, using illustrations, symbols, patterns (samples, templates), and associations. Nancy Margulis gives the principles of creating maps memories developed by their creator Tony Buzan in her work "Maps of the Interior". The main topic is located in the center of the sheet, after that the most important aspects of the topic are mentally selected, and branches from the main problem are drawn. Each subtopic has its main branch, and one word is used for each concept. Where possible, the concept is illustrated. Nancy Margulis recommends making mind maps for at least thirty minutes without distraction. After the creation of the memory map, there is a phase of "smart reading", when, before speaking, speakers quickly check the main ideas, mark the key factors and important details on the map. As a result, the method serves the search, structuring, and timely use of ideas [1, p. 208].

Moreover, we can use this method online. Access students managed to perform different mind mapping tasks with the help of online tools. "Miro" is one of them, for example. It allows to create, broaden, change plenty of schemes and even add a picture of a tree to visualize the task.

Other formats of debates are also productive in foreign language lessons: express debates, debates as a form of work with written or oral text, "speedy" debates, etc.

An express debate is a debate with minimum preparation. They are based on textbook material or handouts and closely intersect with debate as a form of working with a text. An example is the discussion of the topic "Sport damages our health" after reading the thematic text.

When conducting "speed", or mini-debates "one on one", each of the participants has the right to ask two questions to his opponent. The topic of the lesson is some general problem, which is divided into components. For each mini-problem, a pair of competing speakers (two minutes each) are heard, the conclusions of each speaker are recorded and then discussed in the group.

T.V. Oshchepkova, M.M. Prolygin, and D.A. Starkov cite the following types of debates as examples:

1. Controversial ideas

The teacher divides the class into 3 groups. The first group should come up with arguments to support the following statement: "Marriage is a perfect social institution". The second group, on the contrary, must refute this statement and come up with 
arguments to support another statement: "Marriage should be abolished". The task of the third group of students is to take a neutral position on this issue. Pupils in the third group speak out on the following topic: "Marriage laws need performing". At the end of the debate, each student has to decide what position they are taking and why.

Students of the Debate Club "Per aspera ad astra" tried this type of the debate while training their public speaking skills on the topic "What is to be famous?" Participants were divided into 3 groups by the teacher, where 2 of them tried to make PR and anti PR company for famous people and the third one took the neutral position while debating on the question "Do famous people need PR in general?"

2. Text-based debate

Pupils read a text about a particular topic, for example: "Money makes the world go round". After reading the text, students exchange their views, expressing their agreement or disagreement on this issue.

Video-based debate is also possible, and Access students are proof of that. Every topic Access teachers find appropriate and sometimes controversial videos, and the participants' task is sharing their feelings after watching. Learners can say what they liked and disliked and why, which part impressed them most of all, or they can discuss advantages and disadvantages of a certain issue, for example, "Mass media influence".

3. Book-based debate

After reading a book, for example: "The picture of Dorian Gray", students are encouraged to speak on the topic: "Our face or our soul?"

Movie-based, cartoon-based, TV-series-based, TV-show-based debates are also possible. During the first session "Gender Benders" of the "Civil Engagement Club" participants discussed gender stereotypes, particularly, in Disney cartoons. At first, students named cartoons with female and male stereotypes, then modern cartoons where we can see these stereotypes broken. After that learners suggested their own ways of breaking gender benders.

4. Mini-debate

The teacher gives the students a sheet on which certain controversial statements are written. The task of the students is to agree or disagree with them and explain their choice [4, p. 36].

This type of debate is quite popular during the lessons, and the "Civil Engagement Club" is not an exception. Participants have discussions on different important topics, such as volunteering, community service, helping the environment, etc. For instance, students have recently had arguments about the statement "Small acts - big impacts". One half of the students proved that every person is capable to save the planet by doing small steps, while another half tried to disagree because little acts are senseless if people all around the world do not gather.

The fact that the debate is a means of formalizing the discussion seems to be significant. This is especially important in the process of learning a foreign language since conversational topics affect the student's personality more often than in other subjects. Students often find it difficult to present their views on such issues to the class in an informal discussion. The means of overcoming this situation is the formalization of the discussion, i.e. translating it into the mainstream of debates.
In addition, debate teaches schoolchildren to use language clichés correctly in public speaking. The most commonly used are: we suppose, we must confess, we suggest, we believe, the thing is, the fact is, we wonder, the point is, in our opinion, there is something in what you are saying but, we appreciate, thank you for your attention, thank you for the questions and several others. Debates also provide students with an understanding of the structure of speech. An example of a plot speech in "classic" debates is the speech plan of the first speaker: greeting the audience - introducing the team and yourself - introduction (substantiating the relevance of the topic - defining the concepts (definitions) of the topic - putting forward criteria argumentation - conclusion - gratitude for attention. Students' understanding of the structural and plot schemes of the debate will allow them to draw up a plan for most public speaking events in the future.

Access students practiced their public speaking skills with Mr. Patrick Knapp, an American diplomat (a human rights officer) who works at the U.S. Embassy in Kyiv as a special guest on their regular online class. Moreover, participants tried themselves as "actors" and joined "Online Drama Club" with Jean Charles, English Language Fellow. During the rehearsals, learners faced some arguments in organizational skills, so they had to use only a foreign language (English) to make their point and express their opinion.

I.N. Nikulitsa considers debates as a kind of technology for teaching students to speak a foreign language and as a kind of game, which task is to prove the chosen point of view and, observing the logical line of speech (thesis, argument, link-support), to convince the opponent. The author highlights voluntary debates where children choose their team; authoritarian, where the teacher divides children into commands independently, and random [3, p. 38].

Creative techniques for teaching speaking in foreign language lessons include various discussions and debates. While studying the topic "Education" within the framework of the speech situation, students are invited to discuss and find out: "Which school is better: traditional or alternative?" To accomplish this, they are invited to split into two teams supporting different types of schools; time is given for them to prepare statements "for" their school and "against" the school of their opponents. The rules are announced that a discussion will take place within ten minutes, a goal is to convince your opponents that your team's school is better. During the discussion, the teacher writes down the points for each team's persuasive arguments on the board. After the end of the discussion the question is asked: "Are there any team members who were convinced by the rivals and wanted to join them?" and summarized by the number of arguments. Then the teacher analyzes the mistakes encountered during the discussion.

In conclusion, it should be noted that the "debate" technique is relevant and effective and can be used in foreign language lessons in high school. This technique helps to motivate students for further studying of foreign language. The use of debates in teaching the speech interaction of schoolchildren in foreign language lessons contributes to the achievement of successful communication between the participants who are involved in the discussion process, as well as to increase the interest of children in the study of the subject. 


\section{References:}

1. Gorodyanenko V.G. (2002) Sotsiologiya: uch. dlya stud. vysshikh uch. zav. Kyiv: Izd. tsentr "Akademiya», 560 p. (in Russian)

2. Savchenko A.Ya. (1997) Didaktika nachal'noj shkoly. Kyiv: Abris, 420 p. (in Russian)

3. Bose M. (2005) A text book of English Language Teaching for Indian Students. Ch. New Century Book House, 440 p.

4. Crystal D. (2007) English as a global language. Cambridge. Cambridge University Press. 253 p.

5. Gower R. (1995) Teaching Practice Handbook. L. Macmillan Heinemann, 334 p.

6. Kumar J. (1995) Studies in Language Testing 2. Cambridge. University Press, 150 p.

\section{Список літератури:}

1. Городяненко В.Г. Социология : уч. для студ. высших уч. зав. Киев : Изд. центр «Академия», 2002.560 с.

2. Савченко А.Я. Дидактика начальной школы. Киев : Абрис, 1997. 420 c.

3. Bose M. A text book of English Language Teaching for Indian Studentsю Ch. New Century Book House. 2005.440 p.

4. Crystal D. English as a global language. Cambridge : Cambridge University Press, 2007. 253 p.

5. Gower R. Teaching Practice Handbook. L. Macmillan Heinemann. 1995. 334 p.

6. Kumar J. Studies in Language Testing 2. Cambridge : Cambridge University Press, 1995. 150 p. 